\title{
Density responses and spatial distribution of cotton yield and yield components in jujube (Zizyphus jujube)/cotton (Gossypium hirsutum) agroforestry
}

Qi Wang ${ }^{\mathrm{a}}$, Shuo Han ${ }^{\mathrm{e}, \mathrm{a}}$, Lizhen Zhang ${ }^{\mathrm{a}^{*}}$, Dongsheng Zhang ${ }^{\mathrm{a}}$, Wopke van der Werf ${ }^{\mathrm{b}}$, Jochem B. Evers ${ }^{\mathrm{b}}$, Hongquan $\operatorname{Sun}^{\mathrm{c}}$, Zhicheng Su${ }^{\mathrm{c}}$, Siping Zhang ${ }^{\mathrm{d}}$

${ }^{\text {a }}$ China Agricultural University, College of Agricultural Resources and Environmental Sciences, Beijing 100193, China

${ }^{\mathrm{b}}$ Wageningen University, Centre for Crop Systems Analysis (CSA),

Droevendaalsesteeg 1, 6708 PB Wageningen, The Netherlands

${ }^{\mathrm{c}}$ China Institute of Water Resources and Hydropower Research, Beijing, 100038,

China

${ }^{\mathrm{d}}$ Institute of Cotton Research of the Chinese Academy of Agricultural Sciences, State Key Laboratory of Cotton Biology, Anyang, Henan , 455004, China

${ }^{\text {e }}$ Beijing Meteorological Bureau, Beijing, 100089, China

\section{*Corresponding author:}

E-mail: Zhanglizhen@cau.edu.cn (Zhang L.); zhangsp@ cricaas.com.cn (Zhang S.) 


\section{Abstract}

Trees are the dominant species in agroforestry systems, profoundly affecting the performance of understory crops. Proximity to trees is a key factor in crop performance, but rather little information is available on the spatial distribution of yield and yield components of crop species under the influence of trees in agroforestry systems. Also, little information is available on how crop density may be exploited to optimize the yield in such systems. Here we studied the performance of cotton in jujube/cotton agroforestry. Field experiments were conducted in 2012 and 2013 in Hetian, Xinjiang, China. Cotton was grown at a row distance of $60 \mathrm{~cm}$ in three densities, 13.5, 18.0 and 22.5 plants $\mathrm{m}^{-2}$ in six $\mathrm{m}$ wide paths between tree lines in a jujube plantation. Plant density affected both cotton aboveground dry matter and yield significantly. The highest yield was attained at the intermediate density of 18.0 plants $\mathrm{m}^{-2}$ (20.0 plants $\mathrm{m}^{-2}$ corresponding in sole cotton), lower than the optimal density in sole cotton $\left(25.0\right.$ plants $\left.\mathrm{m}^{-2}\right)$. Yield at the lower density was constrained by the low number of bolls per $\mathrm{m}^{2}$ as a direct consequence of the low density, whereas at the high plant density yield was constrained by a lower allocation of assimilates to cotton seed and lint, as a consequence of intraspecific and interspecific competitions. There were strong gradients in yield and yield components in relation to the distance from the tree rows. Leaf area and total dry matter of cotton in rows close to the tree lines were reduced, especially in the rows next to the trees. Moreover, biomass allocation to cotton fruits was reduced in these rows. Competitive influences from the trees on cotton performance extended two rows deep in a six-year old jujube stand, and even 
three rows deep in a seven-year old stand. Shading effects on cotton yield were compensated by increasing plant density as a result of greater boll numbers per unit ground area. Data from this study help guide the design of optimal plant density of cotton in jujube plantations and give insight in the spatial distribution and dynamics of competitive effects in agroforestry systems in general.

Keywords: Border row effect; dry matter partitioning; harvest index; intercropping; specific leaf area

\section{Introduction}

Agroforestry is an intensive land use that combines woody perennials with agricultural crops (Gao et al., 2014). This integration contributes not only to increasing land productivity and resource use efficiencies but also to important ecosystem services such as soil organic matter build-up, enhancing biodiversity and reducing erosion (Garrity, 2004; Smith et al., 2008; Nair et al., 2009; Luedeling, et al., 2014).

The desert climate of the Xinjiang region (northwest China) is suitable for production of cotton (Gossypium hirsutum), and Xinjiang is hence an important cotton producing region. However, fields used for cotton production are susceptible to wind erosion during winter, and one-sided reliance on cotton agriculture poses a risk to the stability of farm incomes (Zhang et al., 2013). To conserve the soil and diversify income sources, farmers in Xinjiang have integrated fruit trees in their crop systems. 
Currently, there is approximately 1.2 million ha of fruit tree/crop mixture in the region (Zhang et al., 2014). Approximately 32,000 ha of agroforestry of jujube tree (Zizyphus jujube) and annuals were developed over the last 10 years near Hetian city, south Xinjiang (Liu et al., 2012). Cotton is the most commonly grown understory crop in young jujube plantations. The jujube/cotton agroforestry system is limited to the first years of jujube growth, when the jujube trees allow sufficient resources between the tree lines for cotton growth. The duration of this window depends on distance between the tree lines as well as the price of cotton and is typically around ten years, similar to for instance poplar/wheat agroforestry in the United Kingdom (van der Werf et al., 2007).

Agroforestry systems support a wide range of biophysical interactions between the crop and the trees (Doufour et al., 2013). Some of the competitive interactions for resources (light, water and mineral elements) have been documented for a variety of practices in the tropics (Cannell et al., 1998; Bellow and Nair, 2003) and constitute a critical factor affecting the yield of cotton in jujube/cotton agroforestry (Gao et al., 2013). Lower light intensity in cotton rows next to the jujube trees might affect cotton leaf growth, assimilate partitioning and yield components. Shaded plants usually have higher specific leaf area (SLA), thinner but wider leaves, and a lower leaf ratio over total biomass (Zhai et al., 2006; Abraham et al., 2014). SLA, i.e. the ratio of the area and dry weight of leaves, is one of the key factors affecting crop biomass production (Wright et al., 2002). Greater SLA allows a plant to capture more light for the same leaf biomass (Reich et al., 1992) which would tend to increase the rate of plant growth. 
However, thin leaves with high SLA tend to be shortlived (Reich et al., 1992), which could diminish the positive effect of SLA on crop growth. The net results of these effects will depend on the exact crop growth conditions.

Within a fruit tree/crop mixture, the trees and the crop compete for light, water and nutrients. Especially during the initial years of a jujube stand, competition from the trees is still small, and the space between the trees might be used for growing crops in order to capture all the radiation and maximize land productivity. Optimal planting densities for the understory crop may be different from those considered optimal for the sole crops because of the competition with the trees. A relationship between distribution of light and cotton yield in jujube/cotton systems has been established (Zhang et al 2014), however little is known on the spatial distribution of cotton leaf area and yield components in such systems. Cotton yield is further determined by the number and growth of bolls containing the cotton seed and fiber (Wells and Meredith, 1984; Boquet et al., 1993; Bange and Milroy 2004).

There is limited knowledge on how sink-source relationships and partitioning of cotton are affected by shading in the agroforestry system, and how these relationships may be manipulated by plant density. Therefore, the objective of this study was to quantify the distribution of cotton leaf area and yield components in jujube/cotton systems as affected by cotton density by testing three cotton plant densities $(13.5,18.0$ and 22.5 plants $\mathrm{m}^{-2}$ ) in a jujube/cotton field.

\section{Materials and Methods}




\subsection{Experiment design}

Field experiments were conducted in 2012 and 2013 at Hetian city (37'9’N, $\left.79^{\circ} 53^{\prime} \mathrm{E}\right)$, in southern Xinjiang, China. The area has a cold desert climate, BWk in the Köppen-Geiger classification (Peel et al., 2007), and is characterized by very low rainfall (37.1 mm per year averaged over 30 years), cold winters, and hot summers. The monthly weather data in two growing seasons are shown in Table 1 . The soil is an arenosol with a bulk density of $1.44 \mathrm{~g} \mathrm{~cm}^{-3}$. Total $\mathrm{N}$ content in the top $30 \mathrm{~cm}$ is $5.8 \mathrm{~g}$ $\mathrm{kg}^{-1}$, Olsen P $21.2 \mathrm{mg} \mathrm{kg}^{-1}$ and $\mathrm{NH}_{4} \mathrm{OAc}$-extractable $\mathrm{K} 51.3 \mathrm{mg} \mathrm{kg}^{-1}$. We used the early maturing cotton (Gossypium hirsutum) variety XLZ46. The jujube (Zizyphus jujube) trees were 6 and 7 years old in the years of this experiment (2012 and 2013). Distance between the tree lines was $6 \mathrm{~m}$, and nine rows cotton were sown at a row distance of $0.6 \mathrm{~m}$ between cotton rows as well as between cotton and tree rows. Distance between trees within a row was $1.25 \pm 0.25 \mathrm{~m}$. Tree height was 2.68 to 2.81 m. The rows had an east-west orientation.

Treatments were conducted in four replicates in a randomized block design and involved three densities of cotton: $13.5,18.0$ and 22.5 plants $\mathrm{m}^{-2}$ of the jujube/cotton system area, corresponding to plant distances in the row of $12.3,9.3$ and $7.4 \mathrm{~cm}$, respectively. Plot area was $60 \mathrm{~m}^{2}$ (10 m length $\times 6 \mathrm{~m}$ width). Cotton was sown on 23 April 2012 and 21 April 2013. The final harvests were made on 15 October 2012 and 13 October 2013. Jujube leaves sprouted at the beginning of May in each year. According to farmers' practice, flood irrigation was applied ten times during the crop growing season, with $50 \mathrm{~mm}$ at each irrigation. Fertilizer was applied at a rate of 300 
$\mathrm{kg} \mathrm{ha}^{-1} \mathrm{~N}$ and $150 \mathrm{~kg} \mathrm{ha}^{-1} \mathrm{P}$ in both years. Soil in the cotton rows was covered with plastic film to increase soil temperature and reduce evaporation (Zribi et al., 2015; Wang et al., 2009). The plant growth regulator mepiquat chloride (MC) was applied four times at a rate of $300 \mathrm{~g} \mathrm{ha}^{-1}$ per application to control the vegetative growth of cotton. The main stem of cotton plant was topped on 15 July of both years to arrest further branch production. Branches were topped on 28 July in both years. Topping main stem and branches was conducted according to farmers' practice in order to prevent the formation of squares that would not be able to develop into mature bolls before the end of the growing season. At the time of topping main stem, the cotton was $65 \mathrm{~cm}$ in height and the $12^{\text {th }}$ fruit branch appeared.

\subsection{Measurements}

Destructive measurements were made over time in each plot to collect data on biomass accumulation in different plant parts and following the development of the plant in terms of the dynamics of the population of organs. A sub-sampling area of 1 $\mathrm{m}$ row length and $6 \mathrm{~m}$ width was selected in each plot in each sampling time. To avoid the influence of density reduction due to removing plants, sub-sampling area was at least $1 \mathrm{~m}$ apart from previous sampling area. Three cotton plants were selected randomly from each row in a sub-sampling area.

To determine aboveground dry matter of cotton, the plant samples were taken on 14 June, 12 July, 13 August, and 23 September in 2012, and on 24 June, 23 July, 20 August and 23 September in 2013. Plant height and the number of leaves, branches 
and fruits were determined. Leaves, stems and fruits were separated to measure leaf area and dry matter of plant organs after drying in an oven at $80{ }^{\circ} \mathrm{C}$ for 2 days to reach a constant weight.

Leaf area of all individual leaves was measured by multiplying the length and width of the leaf with a shape factor of 0.82 (Zhang et al., 2008; Zhang et al., 2014).

Specific leaf area (SLA, $\mathrm{m}^{2} \mathrm{~kg}^{-1}$ ) was obtained by dividing leaf area by total leaf dry weight per plant. To determine the partitioning of dry matter into fruit organs at the boll stage, we computed the ratio of fruit weight to total aboveground dry matter. To determine the proportion of aboveground dry matter to yield, we calculated harvest index as the ratio of seed cotton yield to total aboveground dry matter at harvest.

Final yield of cotton was measured on 15 October 2012 and 13 October 2013. The cotton was harvested once before the first snow. One meter row length was harvested for each row to measure final yield. The seed cotton was sun dried to $13 \%$ water content. To determine yield components, the numbers of plants and bolls (only open bolls) per plant were counted to determine boll density (boll number per unit ground area). A sub-sample of 50 bolls was taken to determine single boll weight and lint (fiber) proportion.

\subsection{Data analysis}

Data of cotton yield, boll density, boll weight, lint proportion and the dynamics of dry matter, leaf area, SLA and ratio of fruit over aboveground dry matter were analyzed using the Univariate General Linear Models procedure of SPSS 21 (IBM, 
USA). The fixed factors in the analysis were plant density and year, while replicate was used as a random factor nested within year. Least significant differences (LSD) were used to separate treatment means at the 0.05 level.

\section{Results}

\subsection{Leaf area and SLA}

Leaf area per $m$ row increased significantly with plant density in all rows, except in the border rows next to the tree lines (Fig. 1a, b). In the second row counting from the tree line, the effect of cotton plant density on leaf area was smaller than in the center rows of the cotton strip. For instance, in 2012, there was a distinct difference in leaf area per $m$ row between the highest and the middle plant density in rows 3 to 7 , but not in rows 2 and 8 . The leaf area in the 5 center rows (the third to fifth rows from the tree lines) was significantly higher than in the first and second rows bordering tree rows in all three density treatments $(P<0.05)$ (Fig. 1a, b). SLA was significantly $(P<0.05)$ higher in border rows than in center rows, indicating shade adaptation (thinner leaves) in the border rows (Fig. 1c, d).

\subsection{Dry matter}

Aboveground dry matter of cotton was significantly affected by plant density $(P<0.05)$. At around 120 days after sowing (DAS), the cotton plants reached their maximum weight (Fig. 2). During late season, there was a trend towards a decrease in weight at 22.5 plants $\mathrm{m}^{-2}$, which was due to shedding of fruits. Eventually, the final 
total dry matter of cotton did not differ significantly between plant densities of 18.0 and 22.5 plants $\mathrm{m}^{-2}$ but total dry matter was significantly lower at 13.5 plants $\mathrm{m}^{-2}$ as compared to the other two densities.

The rows in this system had an east-west orientation. Therefore, we tested whether there were differences in final aboveground dry matter between rows at the south side of the cotton strip (shaded by the nearby tree row to its south) and rows at the north side. We found that plants in rows with the same row number counting from south or north had the same aboveground dry matter $(P>0.05)$ (Fig. 3a, b). There were, however, clear patterns in the differences in dry matter between rows. The dry matter in the first rows bordering tree rows was significantly $(P<0.05)$ lower than in the second border rows from the tree line, and both were substantially lower than aboveground dry weight in the inner 5 rows $(P<0.01)$ in both years. In 2013 , contrary to 2012, there were clear differences in aboveground dry matter between rows 3 to 7 , indicating that the competitive effect of the trees reached two rows deep into the cotton canopy in 2012, but three rows deep in 2013 due to tree growth (Fig. 3a, b).

\subsection{Biomass partitioning and harvest index}

The ratio of fruit over total aboveground dry matter measured at cotton boll stage significantly decreased with plant density in all rows in both years (Fig. 3c, d). This ratio was only $0.3 \mathrm{~g} \mathrm{~g}^{-1}$ in the first two rows next to the tree lines, approximately $40 \%$ lower than in the center rows ( 3 to 7 ), indicating that shading by the trees reduced the biomass allocation to the fruits. 
Harvest index (HI), i.e. the ratio of seed cotton yield to final total aboveground dry matter, was affected by plant density and by row position (Fig. 3e, f). HI was significantly lower at 22.5 plants $\mathrm{m}^{-2}$ than at the other two plant densities, while $\mathrm{HI}$ at 18.0 plants $\mathrm{m}^{-2}$ was significantly different from $\mathrm{HI}$ at 13.5 plants $\mathrm{m}^{-2}$. HI was significantly lower in border rows than in center rows. The small difference between the ratio of fruit over total aboveground dry matter and $\mathrm{HI}$ at different rows, especially at first and second rows bordering tree lines, indicated a difference of the fruit shell weight in relation to the fruit maturity.

\subsection{Yield and yield components}

Seed cotton yield (fiber and seed) was significantly affected by plant density, while the year effect and its interaction with plant density were not significant (Table 2). Average seed cotton yield in the two years at 18.0 plants $\mathrm{m}^{-2}$ was 3.8 ton $\mathrm{ha}^{-1}$, significantly $(5.5 \%)$ higher than at 22.5 plants $\mathrm{m}^{-2}$ and $21.6 \%$ higher than at 13.5 plants $\mathrm{m}^{-2}$. Lint (fiber) yield showed a similar trend (Table 2).

Boll density increased with plant density in both years (Table 2). Boll density at a plant density of 22.5 plants $\mathrm{m}^{-2}$ averaged 148 bolls $\mathrm{m}^{-2}$ over the two years, $8.8 \%$ higher than at 18.0 plants $\mathrm{m}^{-2}$, and $37 \%$ higher than at 13.5 plants $\mathrm{m}^{-2}$. However, single boll weight was decreased at higher plant density. The boll weight at 22.5 plants $\mathrm{m}^{-2}$ was $4.8 \mathrm{~g} \mathrm{boll}^{-1}$ on average over the two years, $8.1 \%$ lower than at 18.0 plants $\mathrm{m}^{-2}$ and $11.4 \%$ lower than at 13.5 plants $\mathrm{m}^{-2}$. There was a significant year effect on boll weight. The higher boll weight in 2013 might be related to the higher air 
temperature during flowering and boll cotton stage (July and August) as compared to 2012. Lint proportion was significantly $(P=0.035)$ decreased by plant density in 2013 , but with only marginal significance $(P=0.083)$ in 2012 .

Yield components all showed a similar pattern across the rows: values were low near the tree lines and peaked in the middle rows. Border row effects on boll number per $\mathrm{m}$ row, single boll weight in a row and lint proportion were significant $(P<0.05)$. The boll numbers per $\mathrm{m}$ row in the first rows bordering tree rows was $50 \%$ below that in the inner 5 rows, while boll number per $\mathrm{m}$ row in the second rows bordering tree rows was reduced by approximately $20 \%$. Increasing plant density significantly increased boll number in rows bordering tree rows (Fig. 4a, b). Single boll weight in the three middle rows was $29 \%$ higher than in the outer border rows (the first to third rows bordering tree lines) in 2012, and 32\% higher in 2013 (Fig. 4c, d). Lint proportion was respectively $26 \%$ and $24 \%$ higher in the three middle rows than in the outer border rows (Fig. 4e, f). Border row effects were broadly similar across plant densities though there is some trend of a larger border row effect on boll weight at highest plant density as compared to the lowest plant density, indicating that using high plant density could compensate the shading effect on yield (Fig. 4c, d).

\section{Discussion and conclusions}

We found the optimal cotton yield was achieved at moderate plant density in jujube/cotton agroforestry, which was consistent to previous studies in sole cotton (Bednarz et al., 2006; Dong et al., 2010). Even though the highest plant density used 
in this study $\left(22.5\right.$ plants $\mathrm{m}^{-2}$ ) had more bolls per $\mathrm{m}^{2}$, single boll weight as well as harvest index were lower than at the optimal plant density. In the sole cotton production in Xinjiang, the plant density according to farmers' practice is around 25.0 plants $\mathrm{m}^{-2}$ due to the dry climate and abundant radiation, which is approximately three times higher than that in the Yellow River and Yangtze River regions in China, where MC is used more sparingly (Dong et al., 2010; Ren et al., 2013). The yield decrease in the jujube/cotton system when going from 18.0 to 22.5 plants $\mathrm{m}^{-2}$ would translate into monoculture densities of 20.0 to 25.0 plants $\mathrm{m}^{-2}$, respectively. This is much lower than the optimal density of 25.0 plants $\mathrm{m}^{-2}$ for sole cotton in Xinjiang, clearly indicating that cotton densities optimal to compete with trees in the agroforestry conditions are well below the densities that cotton can be grown in a monoculture without trees.

In the jujube/cotton system, cotton plants in the first and second rows from the tree lines were strongly restricted in their growth and production, due to competition with the trees. Six-year old jujube trees had significant effects on cotton performance in the two rows at each side of the cotton strip, and one year later effects were noticeable even in the third cotton row from the trees, i.e. up to $1.8 \mathrm{~m}$ from the tree line which is $1.0 \mathrm{~m}$ less than tree height. In jujube/wheat agroforestry, the effects of the trees even extended into the wheat strip over a distance equal to tree height. The interminate growth habit and plastic fruit production of cotton (Gu et al., 2014; Ren et al., 2013) may enable this species to perform relatively well under shade in agroforestry, however, further experiments with variable strip widths and tree heights are needed to explore this in more depth. 
The interaction with the trees resulted in smaller and thinner leaves in border rows, which would affect light interception and light use efficiency of the border row plants and therefore of the system as a whole. The light extinction coefficient in border rows is higher than in center rows in jujube/cotton agroforestry (Zhang et al., 2014), which is due to the changes in leaves size and thickness. The effect of SLA on plant leaf area in border rows was more than offset by the lower total biomass in border rows as a result of shading.

Due to the shading of trees on cotton border rows in agroforestry systems, the tree canopy reduces the incident radiation for the crop (Osman et al., 1998; Doufour et al., 2013). High plant density can be used in principle to attain high radiation interception by the crop (Mao et al., 2014; Zhang et al., 2014).

Border rows had significantly decreased cotton yield and yield components due to the competition by the trees for light (Zhang et al., 2014), water and nutrients (Gao et al., 2013). Yield of cotton in the shade of jujube trees was highest at 18.0 plants $\mathrm{m}^{-2}$, the same density that was found to be optimal for light capture and light use efficiency in cotton/jujube agroforestry (Zhang et al. 2014). That indicates the yield of cotton in the agroforestry heavily depends on competition for light with the trees. It is often thought that row orientation could affect light interception of row or strip crops (Dhingra et al., 1991). If there would have been a row orientation effect, the cotton growing at the north or south side of the strip should have some difference; however such differences were not observed. This lack of orientation effect is consistent with findings in wheat/cotton intercropping (Zhang et al., 2008). The relatively narrow 
path as compared to the tree height may explain the lack of row orientation effect (Midmore, 1993).

The yield and border row effect of cotton in the agroforestry could also be the result of competition for water or nutrients (Lin, 2010). On the other hand, interspecific facilitatory mechanisms may enhance nutrient (nitrogen, phosphorus, and some microelements) acquisition (Li et al., 2013). A higher water use efficiency in maize/cowpea intercropping was found due to the increase of root density in the upper soil layers and a reduction of soil evaporation (Ghanbari et al., 2010).

The spatial distribution of the roots of trees and associated annuals may allow complementarity as a result of spatial or temporal niche differentiation. Jujube trees have, for instance, a deeper and wider root system than wheat, allowing for tree/crop complementarity in jujube/wheat agroforestry (Zhang et al., 2013). How water uptake and use efficiency of jujube and cotton in the jujube/cotton agroforestry are affected by an increase in cotton density may be explored by modeling water-use and light interception in row-structured canopies (Zhang et al., 2008, Miao et al., 2016).

The highest cotton yield at optimal plant density in this study is 1.6 tons ha ${ }^{-1}$, around $70 \%$ of sole cotton $\left(2.3\right.$ tons $\left.\mathrm{ha}^{-1}\right)$. The yield reduction at a plant basis due to the competition of trees is around $20 \%$ when we take into account the $90 \%$ land $(0.6$ $\mathrm{m}$ row space $\times 9$ rows/total width of $6 \mathrm{~m}$ ) covered by cotton in the whole system comparing to sole cotton. The jujube/cotton agroforestry improves the local economy by harvesting additional cotton, as high as $22400 \mathrm{CNY}$ per ha at the optimal plant density of 18.0 plants $\mathrm{m}^{-2}$ (at local lint price of $14 \mathrm{CNY} \mathrm{kg}^{-1}$ ) compared to sole jujube. 
Since the component species in agroforestry may improve each other's environment (Doufour et al., 2013) and produce a myriad of benefits contributing to the ecological and socio-economic sustainability of the farmland and their surrounding landscapes (Gold and Garrett, 2009), the jujube/cotton system might also improve the environmental sustainability by reducing wind erosion and increasing resource use efficiencies. It is necessary to explore social, ecological and economic aspects of this system at a regional level in the future.

In general, cotton plants in border rows had smaller and thinner leaves than plants in center rows, decreased total biomass, a lower biomass fraction in fruit organs, and a reduced fruit number and yield. Shading effects on cotton yield were compensated by increasing plant density to an optimal of 18.0 plants $\mathrm{m}^{-2}$. These results would help farmers optimizing the system by modifying plant density and row arrangement, e.g. by enlarging the distance between cotton border row and jujube trees to minimize the negative effects of the border rows. Without reducing cotton density, narrowing row space to $50 \mathrm{~cm}$ and growing the first cotton row $100 \mathrm{~cm}$ from the jujube trees likely reduces the negative influence of the trees on the cotton plants and might therefore be an option to further increase the productivity of cotton in agroforestry systems.

\section{Acknowledgements}

This research was supported by the International Cooperation and Exchange of

the National Science Foundation of China (31461143025, 31210103906 and 51209220), Transgenic Major Project (2012ZX08013010), '948' Program (2011-G19) 
and the Program of the Modern Agricultural Industry Technology System (CARS-18-18).

\section{References}

Abraham, E.M., Kyriazopoulos, A.P., Parissi, Z.M., Kostopoulou, P., Karatassiou, M., Anjalanidou, K., Katsouta, C., 2014. Growth, dry matter production, phenotypic plasticity, and nutritive value of three natural populations of Dactylis glomerata L. under various shading treatments. Agroforest. syst. 88, 287-299.

Bange, M.P., Milroy, S.P., 2004. Growth and dry matter partitioning of diverse cotton genotypes. Field Crop Res. 87(1), 73-87.

Bednarz, C.W., Nichols, R.L., Brown, S.M., 2006. Plant density modifications of cotton within-boll yield components. Crop Sci. 46, 2076-2080.

Bellow, J.G., Nair, P.K.R., 2003. Comparing common methods for assessing understory light availability in shaded perennial agroforestry systems. Agric. For. Meteorol. 114, 197-211.

Boquet, D.J., Moser, E.B., Breitenbeck, G.A., 1993. Nitrogen effects on boll production of field-grown cotton. Agron. J. 85, 34-39.

Cannell, M.G.R., Mobbs, D.C., Lawson, G.J., 1998. Complementarity of light and water use in tropical agroforests II. Modelled theoretical tree production and potential crop yield in arid to humid climates. For. Ecol. Manage. 102, 275-282.

Dhingra, K.K., Dhillon, M.S., Grewal, D.S., Sharma, K., 1991. Performance of maize and mungbean intercropping in different planting patterns and row orientations. 
Indian J. Agron. 36, 207-212.

Dong, H., Li, W., Xin, C., Tang, W., Zhang, D., 2010. Late planting of short-season cotton in saline fields of the Yellow River Delta. Crop Sci. 50, 292-300.

Doufour, L., Metay, A., Talbot, G., Dupraz, C., 2013. Assessing light competition for cereal production in temperate agroforestry systems using experimentation and crop modelling. J. Agron. Crop Sci. 199, 217-227.

Gao, L., Xu, H., Bi, H., Xi, W., Bao, B., Wang, X., Bi, C., Chang, W., 2013. Intercropping competition between apple trees and crops in agroforestry systems on the Loess Plateau of China. PLoS One 8(7): e70739.

Gao, J., Carla, B., Corinne, V., 2014. A socio-demographic examination of the perceived benefits of agroforestry. Agrofor. Syst. 88, 301-309.

Garrity, D.P., 2004. Agroforestry and the achievement of the millennium development goals. Agrofor. Syst. 61, 5-17.

Ghanbari, A., Dahmardeh, M., Siahsar, B., Ramroudi, M., 2010. Effect of maize (Zea mays L.) - cowpea (Vigna unguiculata L.) intercropping on light distribution, soil temperature and soil moisture in and environment. J. Food Agri. Environ. 8, $102-108$.

Gold, M., Garrett, H., 2009. Agroforestry nomenclature, concepts, and practices. In: Garrett, H.E., Rietveld, W.J., Fisher, R.F. (eds), North American agroforestry: an integrated science and practice. Am. Soc. Agron., Madison, pp 45-56.

Gu, S., Evers, J.B., Zhang, L., Mao, L., Vos, J., Li, Z., 2014. Modelling the structural response of cotton plants to mepiquat chloride and population density. Ann. Bot. 
$114,877-887$.

Li, L., Zhang, L., Zhang, F., 2013. Crop mixtures and the mechanisms of overyielding. In: Levin, S.A., (ed.) Encyclopedia of Biodiversity, second edition, Volume 2, pp. 382-395. Waltham, MA: Academic Press.

Lin, B., 2010. The role of agroforestry in reducing water loss through soil evaporation and crop transpiration in coffee agroecosystems. Agric. For. Meteorol. 150, $510-518$.

Liu, J.Q., Halik, W., Wang, G.S., Kasim, Y., 2012. Study on temporal and spatial distribution rules of characteristic fruit industry resources in Xinjiang. Agric Rea. Arid Areas. 30, 230-236.

Luedeling, E., Kindt, R., Huth, N.I., Koenig, K., 2014. Agroforestry systems in a changing climate-challenges in projecting future performance. Curr. Opin. Environ. Sustain. 6, 1-7.

Mao, L., Zhang, L., Zhao, X., Liu, S., van der Werf, W., Zhang, S., Spiertz, H., Li, Z., 2014. Crop growth, light utilization and yield of relay intercropped cotton as affected by plant density and a plant growth regulator. Field Crops Res. 155, 67-76.

Miao, Q., Rosa, R.D., Shi, H., Paredes, P., Zhua, Li., Dai, J., Goncalves, J.M., Pereira, L.S., 2016. Modeling water use, transpiration and soil evaporation of spring wheat-maize and spring wheat-sunflower relay intercropping using the dual crop coefficient approach. Agri. Water Manage. 165, 211-229.

Midmore, D.J., 1993. Agronomic modification of resource use and intercrop productivity. Field Crops Res. 34, 357-380. 
Nair, P.K.R., Kumar, B.M., Nair, V.D., 2009. Agroforestry as a strategy for carbon sequestration. J. Plant Nutr. Soil Sci. 172, 10-23.

Osman, M., Emminhgam, W.H., Sharrow, S,H., 1998. Growth and yield of sorghum or cowpea in an agrisilviculture system in semiarid India. Agrofor. Syst. 42, 91105.

Peel, M.C., Finlayson, B.L., McMahon, T.A., 2007. Updated world map of the Köppen-Geiger climate classification. Hydrol. Earth Syst. Sci. 11, 1633-1644.

Reich, P.B., Walters, M.B., Ellsworth, D.S., 1992. Leaf life-span in relation to leaf, plant, and stand characteristics among diverse ecosystems. Ecol. Monogr. 62, 365-392.

Ren, X., Zhang, L., Du, M., Evers, J.B., van der Werf, W., Tian, X., Li., Z., 2013. Managing mepiquat chloride and plant density for optimal yield and quality of cotton. Field Crops Res. 149, 1-10

Smith, R.G., Gross, K.L., Robertson, G.P., 2008. Effects of crop diversity on agroecosystem function: crop yield response. Ecosyst. 11(3), 355-366.

Van der Werf, W., Keesman, K., Burgess, P.J., Graves, A.R., Pilbeam, D.J., Incoll, L.D., Metselaar, K., Mayus, M., Stappers, R., van Keulen, H., Palma, J.H.N., Dupraz, C., 2007. Yield-SAFE: a parameter-sparse process-based dynamic model for predicting resource capture, growth and production in agroforestry systems. Ecol. Eng. 29, 419-433.

Wang, F., Feng, S., Hou, X., Kang, S., Han, J., 2009. Potato growth with and without plastic mulch in two typical regions of Northern China. Field Crops Res. 110, 
123-129.

Wells, R., Meredith, W.R., 1984. Comparative growth of obsolete and modern cotton cultivars. III. Relationship of yield to observed growth characteristics. Crop Sci. 24, 868-872.

Wright, I.J., Westoby, M., Reich, P.B., 2002. Convergence towards higher leaf mass per area in dry and nutrient-poor habitats has different consequences for leaf life span. J. Ecol. 90, 534-543.

Zhai, T., Mohtar, R.H., Gillespie, A.R., von Kiparski, G.R., Johnson, K.D., Neary, M., 2006. Modeling forage growth in a Midwest USA silvopastoral system. Agrofor. Syst. 67, 243-257.

Zhang, D., Zhang, L., Liu, J., Han, S., Wang, Q., Evers, J., Liu, J., van der Werf, W., Li, L., 2014. Plant density affects light interception and yield in cotton grown as companion crop in young jujube plantations. Field Crops Res. 169, 132-139.

Zhang, L., van der Werf, W., Bastiaans, L., Zhang, S., Li, B., Spiertz, J.H.J., 2008. Light interception and utilization in relay strip intercrops of wheat and cotton. Field Crops Res. 107, 29-42.

Zhang, W., Ahanbieke, P., Wang, B.J., Xu, W.L., Li, L.h., Christie,P., Li, L., 2013. Root distribution and interactions in jujube tree/wheat agroforestry system. Agrofor. Syst. 87, 929-939.

Zribi, W., Araguiés, R., Medina, E., Faci, J.M., 2015. Efficiency of inorganic and organic mulching materials for soil evaporation control. Soil Tillage Res. 148, $40-45$. 
Table 1 Weather data during cotton growing period in experimental years in Hetian, Xinjiang, China

\begin{tabular}{lrrrrrrrr}
\hline \multirow{2}{*}{ Time } & $\begin{array}{c}\text { Daily maximum air } \\
\text { temperature }\left({ }^{\circ} \mathrm{C}\right)\end{array}$ & \multicolumn{2}{c}{$\begin{array}{c}\text { Daily minimum air } \\
\text { temperature }\left({ }^{\circ} \mathrm{C}\right)\end{array}$} & \multicolumn{2}{c}{$\begin{array}{c}\text { Total sunshine } \\
\text { hours }(\mathrm{h})\end{array}$} & \multicolumn{2}{c}{$\begin{array}{c}\text { Total precipitation } \\
(\mathrm{mm})\end{array}$} \\
\cline { 2 - 9 } & \multicolumn{1}{c}{2012} & 2013 & 2012 & 2013 & 2012 & 2013 & 2012 & 2013 \\
\hline January & -2.3 & 2.2 & -10.7 & -8.0 & 187.0 & 194.1 & 2.5 & 0.1 \\
February & 4.0 & 9.0 & -3.7 & -1.1 & 149.6 & 160.8 & 3.4 & 0.0 \\
March & 14.7 & 20.3 & 3.9 & 8.0 & 199.0 & 222.4 & 11.1 & 0.0 \\
April & 24.7 & 25.0 & 13.1 & 13.1 & 207.8 & 250.7 & 0.1 & 0.0 \\
May & 27.5 & 26.9 & 16.2 & 15.7 & 252.1 & 248.1 & 5.7 & 22.5 \\
June & 30.2 & 32.2 & 19.4 & 19.9 & 250.0 & 274.3 & 33.7 & 10.2 \\
July & 32.2 & 33.2 & 21.2 & 21.2 & 240.6 & 263.2 & 4.0 & 11.6 \\
August & 32.1 & 32.7 & 21.6 & 22.3 & 222.1 & 212.6 & 16.0 & 0.5 \\
September & 28.7 & 28.6 & 17.1 & 16.8 & 253.7 & 238.4 & 0.1 & 0.4 \\
October & 21.4 & 23.4 & 7.9 & 10.4 & 285.4 & 279.4 & 0.0 & 0.0 \\
November & 11.1 & 10.1 & 0.3 & -0.5 & 184.9 & 204.4 & 0.0 & 0.0 \\
December & 4.1 & 3.1 & -5.0 & -5.4 & 175.4 & 181.8 & 3.1 & 0.4 \\
Total & 19.0 & 20.6 & 8.4 & 9.4 & 2607.6 & 2730.2 & 79.7 & 45.6 \\
\hline
\end{tabular}


Table 2 Yield and yield components of cotton in jujube/cotton intercropping in 2012 and 2013 (Hetian, Xinjiang)

\begin{tabular}{|c|c|c|c|c|c|c|}
\hline \multirow[t]{2}{*}{ Year } & Plant density & $\begin{array}{c}\text { Boll } \\
\text { density }\end{array}$ & $\begin{array}{c}\text { Single boll } \\
\text { weight }\end{array}$ & $\begin{array}{c}\text { Lint } \\
\text { proportion }\end{array}$ & $\begin{array}{c}\text { Seed cotton } \\
\text { yield }^{1}\end{array}$ & Lint yield $^{1}$ \\
\hline & plants $\mathrm{m}^{-2}$ & boll $\mathrm{m}^{-2}$ & $\mathrm{~g} \mathrm{boll}^{-1}$ & $\%$ & ton $\mathrm{ha}^{-1}$ & ton $\mathrm{ha}^{-1}$ \\
\hline \multirow[t]{4}{*}{2012} & 13.5 & $107 \mathrm{~b}$ & $5.12 \mathrm{a}$ & $41.5 \mathrm{a}$ & $3.23 \mathrm{c}$ & $1.34 \mathrm{~b}$ \\
\hline & 18.0 & $136 \mathrm{a}$ & $4.84 \mathrm{~b}$ & $40.5 \mathrm{a}$ & $3.90 \mathrm{a}$ & $1.57 \mathrm{a}$ \\
\hline & 22.5 & $147 \mathrm{a}$ & $4.76 \mathrm{~b}$ & $40.4 \mathrm{a}$ & $3.68 \mathrm{~b}$ & $1.48 \mathrm{a}$ \\
\hline & SE & 2.619 & 0.092 & 01.0 & 0.038 & 0.033 \\
\hline \multirow[t]{4}{*}{2013} & 13.5 & $109 \mathrm{c}$ & $5.59 \mathrm{a}$ & $42.1 \mathrm{a}$ & $3.07 \mathrm{~b}$ & $1.29 \mathrm{c}$ \\
\hline & 18.0 & $134 \mathrm{~b}$ & $5.53 \mathrm{a}$ & $41.5 \mathrm{~b}$ & $3.76 \mathrm{a}$ & $1.55 \mathrm{a}$ \\
\hline & 22.5 & $148 \mathrm{a}$ & $4.76 \mathrm{~b}$ & $39.8 \mathrm{c}$ & $3.59 \mathrm{a}$ & $1.43 \mathrm{~b}$ \\
\hline & SE & 1.92 & 0.153 & 0.5 & 0.075 & 0.041 \\
\hline \multirow[t]{4}{*}{ Mean } & 13.5 & $108 \mathrm{c}$ & $5.37 \mathrm{a}$ & $41.8 \mathrm{a}$ & $3.15 \mathrm{c}$ & $1.32 \mathrm{c}$ \\
\hline & 18.0 & $136 \mathrm{~b}$ & $5.18 \mathrm{a}$ & $41.0 \mathrm{a}$ & $3.83 a$ & $1.56 \mathrm{a}$ \\
\hline & 22.5 & $148 \mathrm{a}$ & $4.76 \mathrm{~b}$ & $40.0 \mathrm{a}$ & $3.63 b$ & $1.46 \mathrm{~b}$ \\
\hline & SE & 1.624 & 0.089 & 0.3 & 0.042 & 0.026 \\
\hline \multirow[t]{3}{*}{$P$} & Density & 0.000 & 0.004 & 0.170 & 0.000 & 0.001 \\
\hline & Year & 0.887 & 0.041 & 0.234 & 0.146 & 0.353 \\
\hline & Year $\times$ density & 0.595 & 0.065 & 0.668 & 0.887 & 0.874 \\
\hline
\end{tabular}

Same small letters indicate no significant difference at the 0.05 level between plant densities.

${ }^{1}$ the yields were measured directly by collecting all the bolls from the sampling area at harvesting time. 

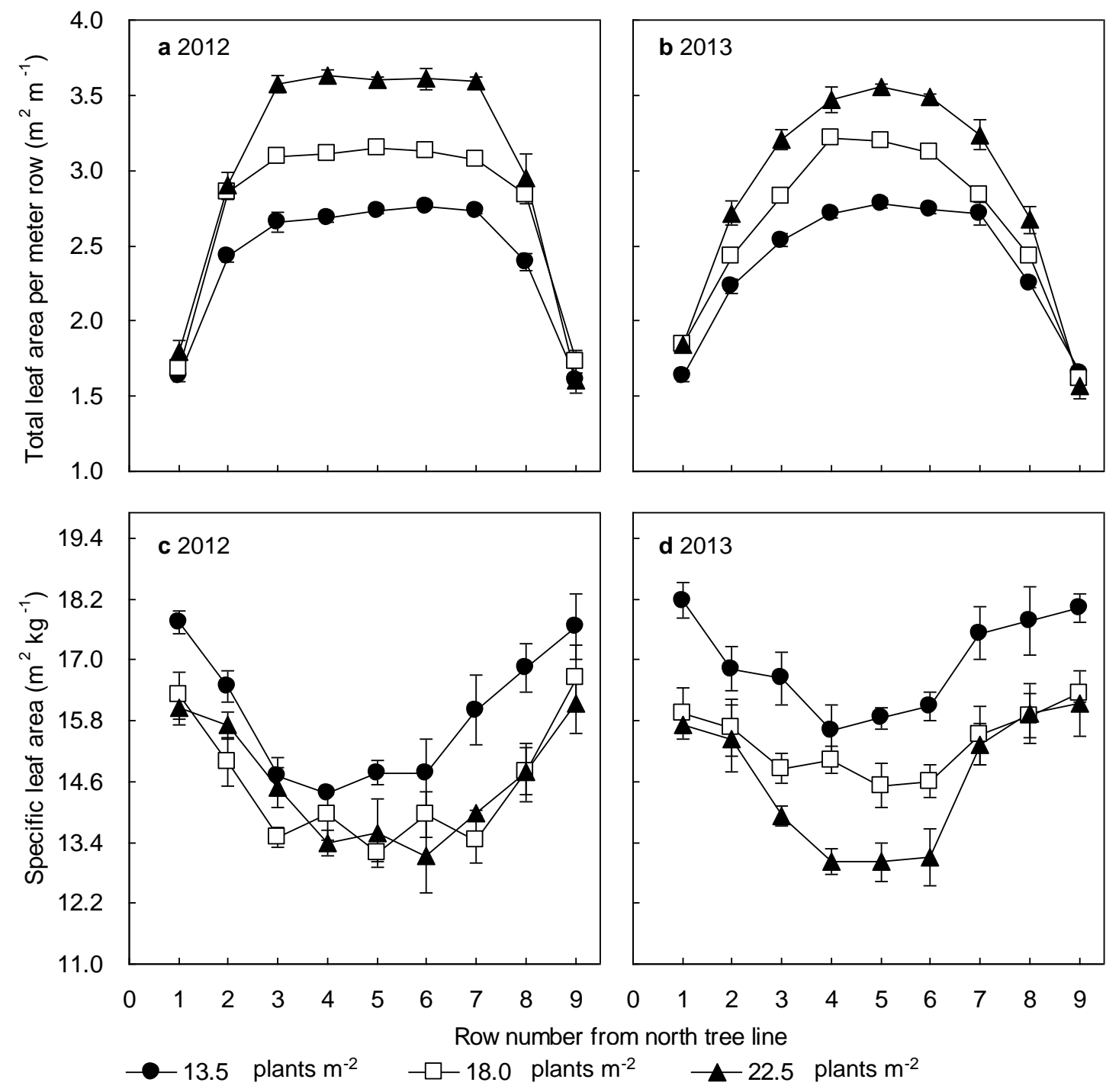

Fig. 1. Leaf area and specific leaf area (SLA) of each cotton row in jujube/cotton intercropping at three plant densities on 9 August 2012 and 20 August 2013 (Hetian, Xinjiang). 


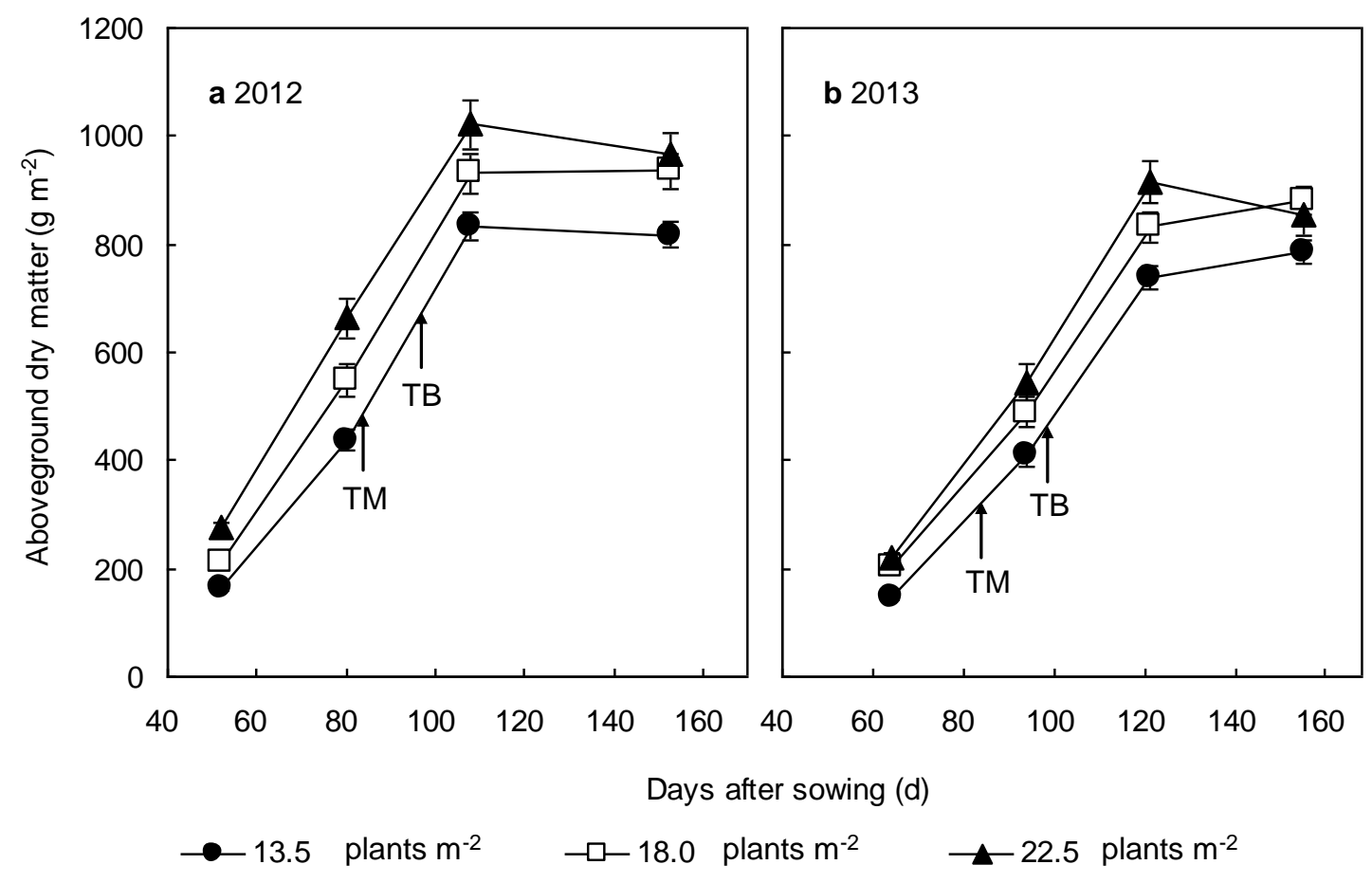

Fig. 2. Aboveground dry matter of cotton averaged over all rows in relation to plant density in jujube/cotton intercropping in 2012 and 2013 (Hetian, Xinjiang). TM and TB indicates the time of topping the main stem and fruit branches, respectively. 

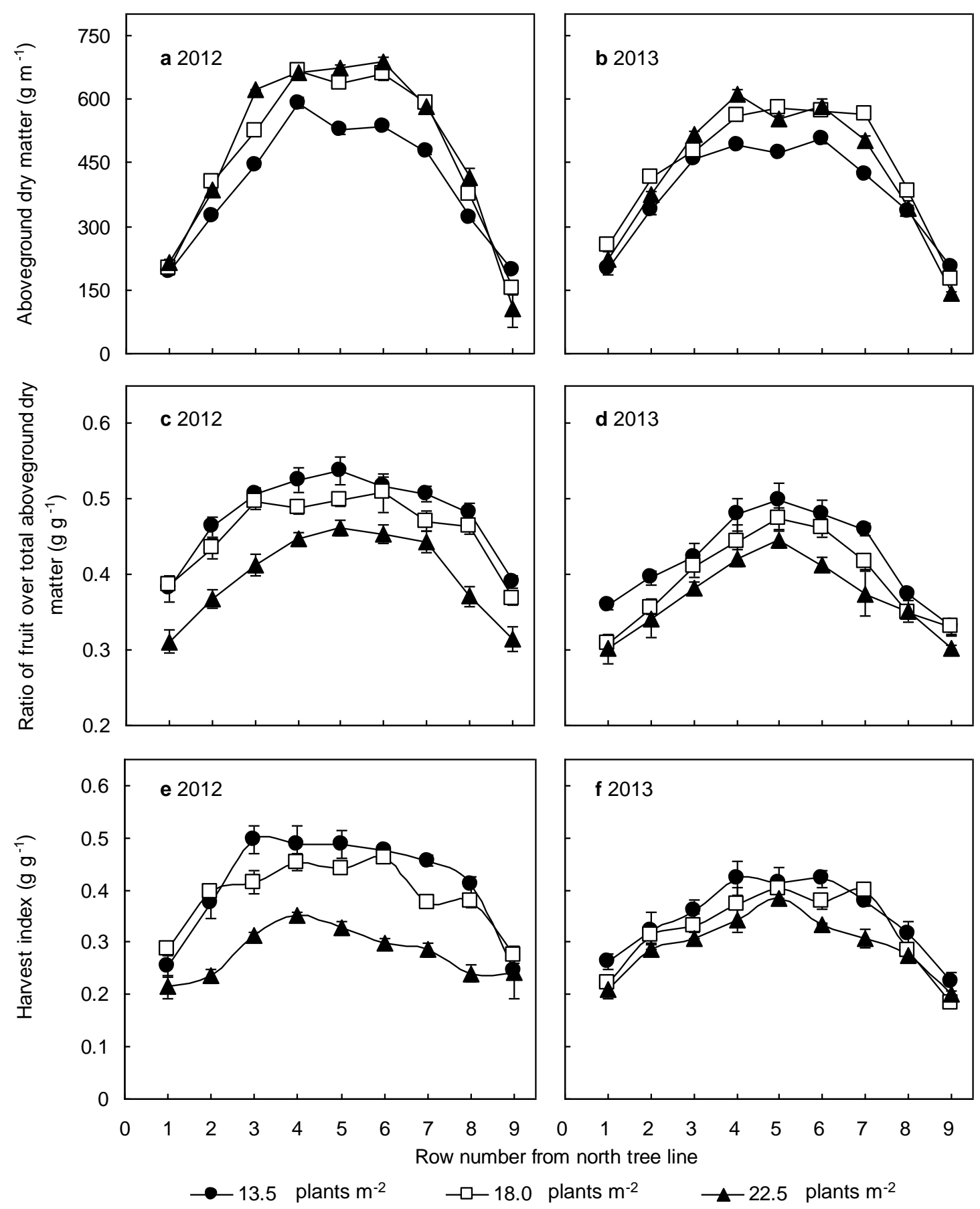

Fig. 3. Plant dry matter, the ratio of fruit over total aboveground dry matter measured on 23 September (at the boll stage) and final harvest index (HI) measured at harvesting time of each cotton row in jujube/cotton intercropping at three plant densities in 2012 and 2013 (Hetian, Xinjiang). 

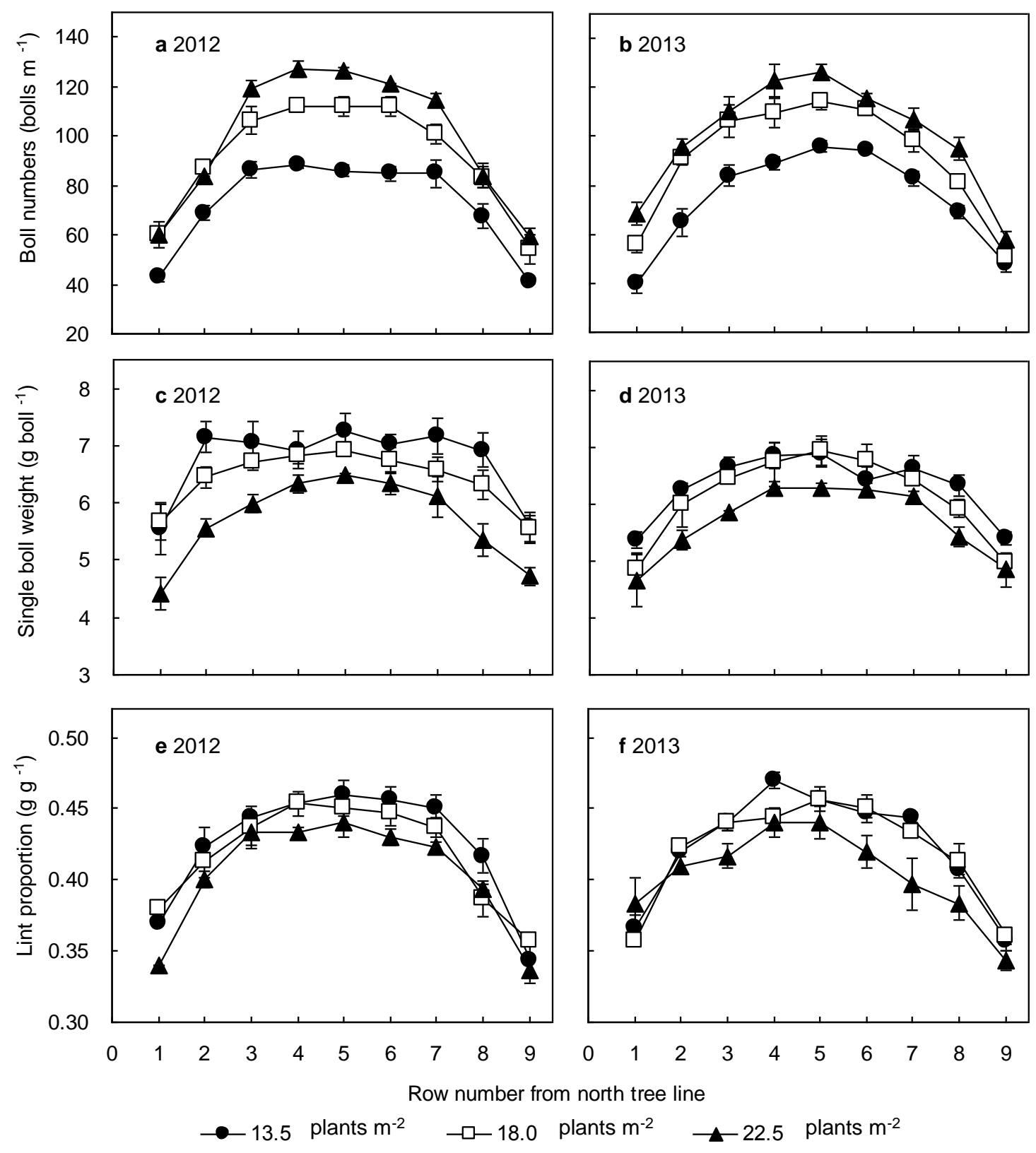

Fig. 4. Spatial distribution of yield components of cotton in jujube/cotton intercropping in 2012 and 2013 (Hetian, Xinjiang). 